\title{
ע Perhetekijöiden yhteys perusopetuksen 8.- ja 9.-luokkalaisten itseraportoimiin luvattomiin koulupoissaoloihin
}

Tutkimuksen tarkoituksena oli kuvata perusopetuksen 8. ja 9. vuosiluokan oppilaiden itseraportoitujen luvattomien koulupoissaolojen määrää sekä tarkastella erilaisten tausta- ja perhetekijöiden yhteyttä luvattomiin poissaoloihin. Taustatekijöinä olivat vastaajan sukupuoli ja luokka-aste sekä vanhempien työllisyystilanne ja koulutustausta. Perhetekijöinä tarkasteltiin perherakennetta, omista asioista keskustelua vanhempien kanssa sekä nuoren ja vanhemman välistä arjen vuorovaikutusta. Tutkimuksen aineisto muodostui Terveyden ja hyvinvoinnin laitoksen Kouluterveyskyselyyn vuonna 2015 vastanneista perusopetuksen 8. ja 9. luokan oppilaista $(n=49$ 256). Kyselyyn vastanneista 8. luokan tytöistä $15 \%$ ja pojista $14 \%$ raportoi vähintään yhden luvattoman poissaolon viimeisen 30 päivän aikana. Luvattomia poissaoloja esiintyi enemmän 9. luokalla: sekä tytöistä että pojista 20\%:lla. Vanhempien heikompi koulutustaso ja työttömyys olivat yhteydessä lisääntyneeseen luvattomien poissaolojen määrään sekä tytöillä että pojilla. Taustatekijöiden ja perhetekijöiden yhteyttä luvattomiin poissaoloihin tarkasteltiin logistisella regressioanalyysillä. Tyttöjen luvattomia poissaoloja selittivät 9. luokka-aste, isän matala koulutus, toisen vanhemman työttömyys, muu kuin kahden vanhemman perherakenne, vähäisempi omista asioista keskustelu ja vähäisempi vuorovaikutus vanhemman kanssa. Pojilla luvattomia poissaoloja selittivät 9. luokka-aste, äidin matala koulutus, molempien vanhempien työttömyys, muu kuin kahden vanhemman perherakenne, vähäisempi kotoa saatu apu koulunkäyntïin ja vähäisempi vuorovaikutus vanhemman kanssa. Luvattomiin poissaoloihin yhteydessä olevien tekijöiden tunnistaminen palveluissa auttaa ymmärtämään perheen merkitystä nuoren elämässä sekä kehittämään koulun ja opiskeluhuollon toimintaa.

ASIASANAT: nuori, perhe, koulupoissaolo EVA AUTIO, ANJA RANTANEN, ANNA-MAIJA KOIVISTO, KATJA JORONEN

JOHDANTO

Kaikki peruskouluikäiset nuoret ovat Suomessa oppivelvollisia, ja heidän on osallistuttava päivittäiseen koulutyöhön. Koulutuksen järjestäjän on lisäksi seurattava oppilaan poissaoloja ja ilmoitettava luvattomista poissaoloista huoltajille. (1.) Lisäksi perusopetuksen opetussuunnitelma (2) edellyttää, että poissaoloja koskeva menettelyohje sisältyy koulukohtaiseen opiskeluhuollon suunni- telmaan. Opiskeluhuollon yhtenä tavoitteena on tarve opintojen edistämiselle hyvinvointia tukevasti, jolloin luvattomien poissaolojen ehkäisy ja puuttuminen ovat keskeinen osa opiskeluhuoltoa. Koulujen seurantavelvoitteesta ja ohjeistuksista huolimatta osalle nuorista kasaantuu toistuvia luvattomia poissaoloja. $(3,4,5)$.

Luvattomien koulupoissaolojen määrää on selvitetty vuodesta 2002 lähtien Kouluterveys- 
kyselyssä. Keskimäärin yhdeksän prosenttia perusopetuksen 8. ja 9. luokan oppilaista kertoo olleensa vähintään kaksi päivää luvattomasti pois koulusta viimeisen kuukauden aikana. Luvattomien poissaolojen määrä on pysynyt seuranta-aikana samana eikä sukupuolten välillä ole eroja. (6.)

Kirjallisuudessa luvattomista koulupoissaoloista puhutaan kolmella käsitteellä: luvaton poissaolo (truancy), koulukieltäytyminen (school refusal behavior) ja koulupelko (school phobia) $(7,8)$. Koulukieltäytymisen synonyyminä käytetään myös käsitettä koulupelko (9). Omaksi ryhmäkseen erotetaan vielä ryhmä, jossa on sekä luvallista että luvatonta poissaoloa $(10,11,12)$. Luvattomia poissaoloja kuvaavia käsitteitä käytetään vaihdellen eikä niitä ole yhdenmukaisesti määritelty $(7,13,14,15)$. Luvaton poissaolo (truancy), joka on tämän tutkimuksen kohteena, on määritelty aiemmissa tutkimuksissa poissaoloksi koulusta vanhempien tietämättä ilman poissaoloon hyväksyttävää syytä $(10,16,7,14)$.

Useat kansainväliset tutkimukset ovat osoittaneet luvattomien poissaolojen olevan yhteydessä useisiin hyvinvointia uhkaaviin tekijöihin. Luvattomilla poissaoloilla on osoitettu olevan yhteyttä lisääntyneeseen päihteiden käyttöön (17, $18,19,20,21,22)$. Luvattomasti koulusta poissaolevilla nuorilla on havaittu myös viisi kertaa korkeampi riski tapaturmakuolleisuuteen (23). Luvattomasti poissaolevien nuorten käytöksessä on havaittu enemmän rikollista käytöstä kuin oppilailla, joilla on koulupelkoa tai oppilailla, jotka käyvät säännöllisesti koulua (19). Luvattomasti poissaolevien nuorten käytöksessä on todettu myös enemmän keskittymisvaikeuksia ja levottomuutta. Toisaalta heikon itsetunnon ei ole todettu olevan yhteydessä luvattomiin poissaoloihin koulusta. (24.)

Kotona ja koulussa esiintyvien sosiaalisissa suhteissa olevien vaikeuksien on todettu lisäävän nuoren luvattomien poissaolojen määrää. (25). Toisaalta ahdistuneisuuden ei ole todettu olevan yhteydessä luvattomiin poissaoloihin. (7). Sen sijaan masennuksen todennäköisyys on todettu olevan luvattomasti poissaolevilla tytöillä yleisempää kuin luvattomasti poissaolevilla pojilla (5). Sosiaalisten tilanteiden pelon ja samanaikaisen masennuksen on todettu lisäävän nuoren poissaoloja koulusta (27). Luvattomien poissaolojen ja koulukieltäytymisen taustalla on todet- tu esiintyvän sosiaalisia ongelmia, jotka voivat johtaa epäsosiaaliseen käytökseen (8).

Aiempien tutkimusten mukaan monet perheen elinoloja ja perhettä kuvaavat tekijät ovat myös yhteydessä nuoren luvattomiin koulupoissaoloihin. Perheen taloudellinen tilanne $(28,22)$, vanhempien työtilanne $(15,26)$, perherakenne $(29,28)$, vanhempien koulutustausta $(18,30)$ ja vanhemman huolenpito $(31,32)$ ovat yhteydessä eri lailla oireilevien nuorten koulupoissaoloihin. Perheen vuorovaikutussuhteilla on myös todettu yhteys nuoren luvattomiin koulupoissaoloihin $(11,21,26,32,30)$. Perheen sisäisillä tapahtumilla, kuten esimerkiksi läheisen kuolemalla ja vakavilla sairauksilla on todettu olevan yhteyttä nuoren luvattomiin poissaoloihin. Lisäksi vanhempien päihteidenkäytöllä ja heikommalla terveydentilalla on havaittu olevan yhteys nuoren lisääntyneisiin luvattomiin poissaoloihin. $(40,30,8,21$, 29, 26.)

Nuoren psyykkisen hyvinvoinnin ja päihteiden käytön yhteyttä koulupoissaoloihin on tutkittu sekä kansainvälisissä että kotimaisissa tutkimuksissa. Yläkouluikäisten itsearvioimia luvattomia koulupoissaoloja ja niihin yhteydessä olevia perhetekijöitä on tutkittu melko paljon kansainvälisesti, mutta suomalainen tutkimus on vähäistä.

Perhetekijöiksi on määritelty muun muassa perherakenne, vanhempien työllisyystilanne ja koulutus. Perhetekijöillä viitataan perheeseen liittyviin ilmiöihin ja tapahtumiin. Tässä tutkimuksessa perhetekijöillä tarkoitetaan perherakennetta, nuoren ja vanhemman välistä keskusteluyhteyttä, kotiintuloajoista sopimista, vanhempien tietoa nuoren iltojen ja viikonloppujen vietosta, vanhempien keskusteluyhteyttä nuoren ystävien kanssa sekä nuoren vanhemmiltaan saamaa tukea ja kannustusta

\section{AIEMMAT TUTKIMUKSET PERHETEKIJÖIDEN YHTEYDESTÄ NUORTEN LUVATTOMIIN KOULU- POISSAOLOIHIN}

Aiemmat tutkimukset ovat osoittaneet vanhempien taloudellisen tilanteen olevan yhteydessä nuorten luvattomiin koulupoissaoloihin. Vanhempien kuuluminen ylempään palkkaluokkaan on todettu vähentävän nuorten poissaoloja koulusta (33) ja vastaavasti matalan tulotason perheen nuorilla on havaittu enemmän poissaoloja $(11,25$, $28,24,22,35,36,37)$. Perheen heikon taloudellisen 
tilanteen on tunnistettu vaikuttavan negatiivisesti vanhemmuuteen, mikä saattaa siten olla yhteydessä poissaoloihin $(29,32,38)$.

Vanhempien työttömyydellä on todettu olevan yhteys nuoren luvattomiin poissaoloihin. Toisen tai molempien vanhempien työttömyyden on havaittu olevan luvattomien koulupoissaolojen riskitekijä $(40,15,26,39)$. Vanhempien työllisyys on yhteydessä nuoren terveyteen ja hyvinvointiin, mikä saattaa näin olla yhteydessä säännölliseen koulunkäyntiin (15).

Vanhempien matalalla koulutustaustalla on osoitettu yhteys nuorten luvattomiin poissaoloihin $(18,33,30,39)$. Erityisesti äidin alhainen koulutustaso on näyttänyt lisäävän nuoren poissaoloja $(33,29,26,36)$ ja vastaavasti isän korkean koulutustason vähentävän luvattomia poissaoloja (15). Äidin tai isän yliopistotutkinto näyttäisi olevan yhteys nuoren säännöllisen koulunkäyn$\operatorname{nin}(41,18)$.

Aiemmissa tutkimuksissa perherakenteella on havaittu olevan yhteys nuoren luvattomiin koulupoissaoloihin. Yksinhuoltajaperheessä elämisen on osoitettu olevan yhteys luvattomiin poissaoloihin $(41,18,33,28,29)$. Vanhempien avioero, erillään asuminen tai nuoren yksinasuminen on tunnistettu olevan yhteydessä nuoren epäsäännölliseen koulunkäyntiin ja lisäävän poissaoloja $(33,30)$. Perherakenteen yhteys luvattomiin poissaoloihin ei ole tutkimusten mukaan kuitenkaan yksiselitteistä. Yhtäältä tutkimustuloksissa on viitteitä siitä, ettei yhden vanhemman perheessä eläminen lisäisi koulupoissaoloja, mutta toisaalta nuorista, joilla esiintyi jatkuvasti luvattomia koulupoissaoloja, puolella oli tapahtunut perherakenteen muutoksia $(42,43)$.

Aiempien tutkimusten mukaan vanhempien osallistuminen nuoren elämään näyttäisi olevan yhteydessä luvattomiin koulupoissaoloihin (25, 22). Esimerkiksi vanhempien heikon valvonnan on todettu riskitekijäksi poissaoloille $(17,39,18$, $44,14,19,33,21,24)$. Tutkimustulokset ovat toisaalta olleet ristiriitaisia; on havaittu, että vanhempien liiallinen valvonta ja kontrolli lisäävät poissaoloja (33). Useissa tutkimuksissa on tuotu esille vanhemmilta saadun huolenpidon ja vastuuntunnon puutteen olevan yhteydessä nuoren koulupoissaoloihin $(38,33,31,32)$. Perheen yhteenkuuluvuuden tunne näyttäisi olevan yhteydessä nuoren vähäisempiin luvattomiin poissaoloihin (33). Vanhempien luoma turvallisuuden tunne saattaa olla suojaava tekijä, joka vähentää poissaoloja ja vastaavasti heikko vanhempi-lapsi-suhde saattaa olla lisäävä tekijä $(32,30)$.

Vanhempien omilla ongelmilla on todettu olevan yhteys nuoren koulupoissaoloihin. Vanhempien parisuhdeongelmat, kuten avioero on yhteydessä poissaoloihin koulusta $(25,30)$. Vanhempien päihteiden käytöllä ja heikommalla fyysisellä ja psyykkisellä terveydentilalla, kuten masennuksella, on osoitettu olevan yhteys nuoren luvattomiin poissaoloihin $(8,21,29,26,40)$.

\section{TUTKIMUKSEN TARKOITUS}

Tutkimuksen tarkoituksena oli kuvata perusopetuksen 8. ja 9. vuosiluokan oppilaiden itseraportoitujen luvattomien koulupoissaolojen määrää sekä tarkastella erilaisten tausta- ja perhetekijöiden yhteyttä luvattomiin poissaoloihin. Taustamuuttujina olivat nuoren sukupuoli ja luokkaaste, vanhempien työllisyystilanne ja vanhempien koulutus. Perhetekijöinä tarkasteltiin perherakennetta, nuoren omista asioista keskustelua vanhempiensa kanssa sekä nuoren ja vanhemman välistä arjen vuorovaikutusta.

\section{TUTKIMUSAINEISTO JA MENETELMÄT}

Tutkimusaineistona oli valtakunnallisen Kouluterveyskyselyn aineisto vuodelta 2015. Tutkimusasetelma oli poikkileikkaustutkimus. Tutkimuksessa kohderyhmänä oli perusopetuksen 8. ja 9. luokan oppilaat. Kysely toteutettiin pääosin oppilaitoksen tietokoneella nimettömänä luokkakyselynä huhtikuussa 2015, ja vastaaminen oli oppilaille vapaaehtoista. Oppilaita ja huoltajia tiedotettiin tutkimuksesta. Kyselyyn vastasi 50 404 peruskoulun 8. ja 9. luokan oppilasta. (45.) Aineistosta on poistettu niiden nuorten vastaukset, jotka olivat vastanneet alle puoleen kysymyksistä $(1,3 \%)$, eivät olleet ilmoittaneet sukupuoltaan $(0,7 \%)$ tai luokka-astettaan $(0,4 \%)$. Vuonna 2015 kyselyn toteutuksessa esiintyi teknisiä ongelmia, jonka vuoksi vastausaktiivisuus jäi tavanomaista suppeammaksi (43\%).

\section{MITTARI}

Tässä tutkimuksessa käytettiin Kouluterveyskyselyn kysymyksiä. Kyselylomake sisältää kysymyksiä eri aihealueista, kuten terveydestä, perheestä, elinoloista, koulunkäynnistä ja opiskelusta. Selitettävänä muuttujana tässä tutkimuksessa oli luvattomat koulupoissaolot. Koulupoissaolon 
määrää selvitettiin kysymyksellä: ”Kuinka monta kokonaista koulupäivää olet ollut lintsauksen takia poissa viimeisten 30 päivän aikana?" Vastausvaihtoehdot olivat: "en yhtään", "yhden päivän", "2-3 päivää" ja "yli 3 päivää". Jatkoanalyysia varten muuttuja luokiteltiin uudelleen kaksiluokkaiseksi. Vastausvaihtoehto "En yhtään" säilytettiin ja muut vastausvaihtoehdot yhdistettiin luokaksi "Vähintään yksi päivä".

Selittävänä muuttujana oli vastaajan taustaja perhetekijät. Taustatekijöinä olivat vastaajan ikä, luokka-aste, vanhempien koulutus ja työllisyystilanne. Luokka-asteella selvitettiin oliko vastaaja 8. vai 9. luokan oppilas. Vanhempien työllisyystilannetta kysyttiin kysymyksellä: "Ovatko vanhempasi olleet viimeisen kuluneen vuoden aikana työttöminä tai lomautettuina?" Vastausvaihtoehdot olivat: "ei kumpikaan", "toinen vanhemmista", "molemmat vanhemmat". Nuorilta kysyttiin vanhempien koulutuksesta seuraavasti: "Mikä on korkein koulutus, minkä vanhempasi ovat suorittaneet?". Vastausvaihtoehdot olivat erikseen äidille ja isälle "peruskoulu tai vastaava", "lukio tai ammatillinen oppilaitos", "lukion tai ammatillisen oppilaitoksen lisäksi ammatillisia opintoja", "yliopisto, ammattikorkeakoulu tai muu korkeakoulu".

Perhetekijöitä tarkasteltiin yhdeksällä strukturoidulla kysymyksellä. Perherakennetta selvitettiin vastaajilta kysymyksellä: "Keiden aikuisten kanssa asut?" Vastausvaihtoehtoina olivat: ”äidin ja isän kanssa”, ”äidin ja isän kanssa vuorotellen, he eivät asu yhdessä", "vain äidin kanssa”, "vain isän kanssa”, ”äidin/isän ja hänen kumppaninsa kanssa", "sijaisperheessä", "muun huoltajan kanssa", "lastensuojelulaitoksessa”, "muun aikuisen tai aikuisten kanssa" tai "asun muulla tavoin". Perherakenne luokiteltiin uudelleen ja luokat nimettiin uudelleen. Luokka ”äidin ja isän kanssa” muodosti luokan "kahden vanhemman perhe" ja "äidin ja isän kanssa vuorotellen, he eivät asu yhdessä" muodosti luokan "vuoroasuminen”. Muuttujan luokat "vain äidin kanssa" ja "vain isän kanssa" yhdistettiin ja nimettiin luokaksi "yhden vanhemman perhe". Vastausvaihtoehto "äidin/isän ja hänen kumppaninsa kanssa" nimettiin luokaksi "uusperhe". Luokat "sijaisperheessä", "muun huoltajan kanssa", "lastensuojelulaitoksessa", "muun aikuisen tai aikuisten kanssa" ja "asun muulla tavoin" yhdistettiin ja nimettiin luokaksi "muul- la tavoin”. Omista asioista keskustelua vanhempien kanssa kysyttiin kysymyksellä: "Pystytkö keskustelemaan vanhempiesi kanssa omista asioistasi?" Vastausvaihtoehtoina käytettiin 4-portaista Likert-asteikkoa (usein - ei juuri koskaan). Nuorilta pyydettiin arvioita myös kotoaan saamastaan avusta koulunkäyntiin: ”Jos sinulla on vaikeuksia koulunkäynnissä, kuinka usein saat apua?" Vastausvaihtoehtona käytettiin 4-portaista Likert-asteikkoa (aina kun tarvitsen - en juuri koskaan).

Nuoren ja vanhemman välistä arjen vuorovaikutusta kysyttiin kuudella kysymyksellä. Nuoren ja vanhemman välistä keskustelua nuoren koulupäivästä kysyttiin: "Kuinka usein keskustelut vanhempiesi kanssa koulupäivästäsi?”. Kotiintuloajoista sopimista tarkasteltiin kysymyksellä: "Sovitte kotiintuloajoista, kun lähdet ulos". Vanhempien tietoisuutta nuoren iltojen ja viikonloppujen vietosta kysyttiin: "Salaat vanhemmiltasi, mitä teet iltaisin ja viikonloppuisin". Nuorilta pyydettiin myös arviota, miten vanhemmat huomioivat nuoren ystävät: "Vanhempasi juttelevat ystäviesi kanssa heitä tavatessaan”. Nuoren ja vanhemman välisistä riidoista pyydettiin nuoren arvioita: "Riitelet vanhempiensa kanssa". Lisäksi nuorelta kysyttiin kokemusta vanhemmaltaan saamasta tuesta seuraavasti: "Vanhempasi tukevat ja kannustavat sinua”. Väittämät vanhempien tietoisuudesta nuorten iltojen ja viikonloppujen vietosta sekä nuoren arvio riidoista vanhempiensa kanssa käännettiin yhdenmukaiseksi muiden kysymysten kanssa. Kääntämisen jälkeen vastausvaihtoehdot koodattiin uudelleen. Uudelleenkoodaamisen jälkeen vastausvaihtoina käytettiin edellä mainittujen väittämien kohdalla 4-portaista Likert-asteikkoa (usein - ei juuri koskaan), jolloin vastausvaihtoehdon pieni luku merkitsi negatiivista ja suuri luku myönteistä vuorovaikutusta. Vanhemman ja nuoren välistä vuorovaikutusta selvittävistä kysymyksistä muodostettiin keskiarvosummamuuttuja (Cronbachin alfa 0,61 ).

\section{AINEISTON ANALYYSI}

Aineiston kuvailu aloitettiin tarkastelemalla muuttujien frekvenssi- ja prosenttijakaumia. Vastaajien iän tarkastelussa käytettiin keskiarvoa ja keskihajontaa, ja sukupuolten välistä eroa selvitettiin riippumattomien otosten t-testin avulla. Keskiarvosummamuuttujan tarkastelussa suku- 
puolten sekä poissaolijoiden ja ei-poissaolijoiden välisen tilastollista merkitsevyyttä tutkittiin t-testin avulla. Analyysia jatkettiin tarkastelemalla ristiintaulukoinnin avulla tausta- ja perhetekijöiden yhteyttä luvattomiin poissaoloihin. Khiin neliö -testin avulla tarkasteltiin muuttujien välisen yhteyden tilastollista merkitsevyyttä. Logistisella regressioanalyysilla selvitettiin tausta- ja perhetekijöiden yhteyttä luvattomiin poissaoloihin. Ensin selvitettiin yksittäisen selittävän muuttujan (tausta- ja perhetekijät) yhteyttä selitettävään (luvaton koulupoissaolo) muuttujaan tytöillä ja pojilla (vakioimaton). Seuraavaksi kaikki taustaja perhemuuttujat otettiin yhtä aikaa samaan malliin (vakioitu) ja tarkasteltiin niiden yhteyttä luvattomiin poissaoloihin. Yhteyksien voimakkuutta raportoitiin mukana olleiden tekijöiden ristitulosuhteilla (OR) ja niiden 95 prosentin luottamusväleillä (lv) sekä p-arvoilla. Tilastollisen merkitsevyyden rajaksi asetettiin $\mathrm{p}<0.001$ aineiston suuren koon vuoksi. Aineisto analysoitiin SPSS for Windows 24 tilasto-ohjelmalla.

\section{TULOKSET}

\section{VASTAAJIEN TAUSTATIEDOT}

Vastaajista noin puolet oli tyttöjä $(\mathrm{n}=24$ 784) ja puolet poikia ( $n=24472)$. Vastaajien keski-ikä oli 15 vuotta $(\mathrm{kh}=0,62)$. Noin puolet vastaajista oli 8.-luokkalaisia ja puolet 9.-luokkalaisia. Vanhempien koulutus oli samankaltainen sekä tyttöjen että poikien vanhemmilla. Vastaajien äideistä $36 \%$ :lla ja isistä $31 \%$ :lla oli yliopisto-, ammattikorkeakoulu tai muu korkeakoulututkinto. Kyselyyn osallistuneiden äideistä $7 \%$ :lla ja isistä $10 \%:$ :lla korkein koulutus oli peruskoulu tai vastaava. Kolmasosalla vastaajista jompikumpi vanhemmista oli ollut työttömänä tai lomautettuna kuluneen vuoden aikana. Vastaajista $4 \%: 1 l a$ molemmat vanhemmat olivat olleet työttöminä vuoden aikana. (Taulukko 1.)

\section{VASTAAJIEN PERHETEKIJÄT}

Suurin osa tytöistä $(66 \%)$ ja pojista $(67 \%)$ asui kahden vanhemman perheessä. Vanhempien luona vuorotellen asuminen eli niin sanottu vuoroasuminen oli pojilla hieman yleisempää kuin tytöillä. Tytöistä yhden vanhemman perheessä tai uusperheessä asui hieman useampi, ja vastaavasti pojista useampi ilmoitti asuinmuodoksi muun ta- van. Pojista hieman useampi (37\%) kuin tytöistä (32\%) keskusteli vanhempiensa kanssa omista asioistaan usein. Tyttöjen kokema kotoaan saama apu koulunkäyntiin oli vähäisempää kuin pojilla. Tytöistä $17 \%$ ja pojista $13 \%$ ilmoitti saavansa harvoin tai ei juuri koskaan tarvittaessa kotoaan apua koulunkäyntiin.

Nuoret arvioivat, että hyvä vuorovaikutus arjessa vanhempien kanssa toteutui keskimäärin melko usein. Poikien (ka 2,94, kh 0,53) kokemus vuorovaikutuksesta oli hieman tyttöjä (ka 3,06, kh 0,56) heikompi $(\mathrm{p}<0,001)$. (Taulukko 2.)

\section{LUVATTOMAT POISSAOLOT}

Suurin osa ( $83 \%)$ kyselyyn vastanneista tytöistä ja pojista ei ollut raportoinut yhtään luvatonta poissaoloa viimeisen 30 päivän aikana. Yhden päivän poissaolo oli $9 \%$ :lla vastaajista. Tytöillä $(14 \%)$ korkeintaan kolmen päivän poissaoloja oli hieman enemmän kuin pojilla (12\%). Yli kolmen päivän poissaoloja esiintyi pojilla $(5 \%)$ tyttöjä (4\%) lähes yhtä paljon. (Taulukko 3.)

\section{TAUSTATEKIJÖIDEN YHTEYS LUVATTOMIN KOULUPOISSAOLOIHIN}

Kaikilla taustatekijöillä oli tilastollisesti merkitsevä yhteys sekä tyttöjen että poikien kohdalla vähintään yhden päivän luvattomaan poissaoloon $(\mathrm{p}<0,001)$. Tyttöjen ja poikien itseraportoimia poissaolopäiviä oli enemmän 9. luokalla kuin 8 . luokalla. Joka viidennellä 9. luokan oppilaalla oli vähintään yksi luvaton poissaolo viimeisen kuukauden aikana. Vanhempien koulutustaustalla oli yhteys nuoren luvattomiin poissaoloihin. Vähintään yhden päivän luvaton poissaolo oli harvinaisempaa korkeasti koulutettujen vanhempien perheissä. Vanhempien ollessa korkeasti koulutettuja vähintään yhden päivän luvattomia poissaoloja oli $14 \%$ :lla tytöistä ja pojista. Äidin tai isän korkeimman koulutuksen ollessa peruskoulu tai vastaava luvattomia poissaoloja oli lähes $30 \%$ :lla tytöistä ja pojista. Myös vanhempien työllisyystilanteella oli yhteys sekä tyttöjen että poikien luvattomiin poissaoloihin. Perheissä, joissa ei ollut työttömyyttä, sekä tytöistä että pojista $15 \%: 1 l a$ oli luvattomia poissaoloja. Poissaoloja esiintyi enemmän nuorilla, joiden vanhemmilla oli ollut työttömyyttä. Nuoren molempien vanhempien ollessa työttöminä tai lomautettuina poissaoloja oli tytöistä runsaalla neljäsosalla $(27 \%)$ ja pojista kolmasosalla (32\%). (Taulukko 4.) 
Taulukko 1. 8.- ja 9.-luokkalaisten tyttöjen ja poikien taustatekijät (THL Kouluterveyskysely 2015)

\begin{tabular}{|c|c|c|c|c|}
\hline \multirow[b]{2}{*}{ Taustatekijät } & $\begin{array}{l}\text { Koko aineisto } \\
(\mathrm{n}=49256)\end{array}$ & $\begin{array}{l}\text { Tytöt } \\
(\mathrm{n}=24784)\end{array}$ & $\begin{array}{l}\text { Pojat } \\
(\mathrm{n}=24472)\end{array}$ & \multirow[b]{2}{*}{$\mathrm{p}$-arvo } \\
\hline & & & & \\
\hline \multirow{3}{*}{$\begin{array}{l}\text { Ikä min-max } \\
\mathrm{Ka} \pm \mathrm{kh}\end{array}$} & $12,25-17,25$ & $12,25-17.25$ & $12,33-17.25$ & \multirow[t]{2}{*}{$<0,001$} \\
\hline & $15,34 \pm 0,62$ & $15,35 \pm 0,63$ & $15,33 \pm 0,61$ & \\
\hline & $\%(\mathrm{n})$ & $\%(\mathrm{n})$ & $\%(n)$ & \multirow{4}{*}{$0,012^{2}$} \\
\hline \multirow{3}{*}{$\begin{array}{l}\text { Luokka-aste } \\
\text { 8. luokka } \\
\text { 9. luokka }\end{array}$} & & & & \\
\hline & $50,5(24882)$ & $50,0(12380)$ & $51,1(12502)$ & \\
\hline & $49,5(24374)$ & $50,0(12404)$ & $48,9(11970)$ & \\
\hline \multirow{5}{*}{$\begin{array}{l}\text { Äidin koulutus } \\
\text { Peruskoulu tai vastaava } \\
\text { Lukio tai ammatillinen oppilaitos } \\
\text { Lukio tai ammatillisen oppilaitoksen } \\
\text { lisäksi ammatillisia opintoja } \\
\text { Yliopisto, ammattikorkeakoulu tai } \\
\text { muu korkeakoulu }\end{array}$} & & & & \multirow{5}{*}{$0,008^{2}$} \\
\hline & $7,1(3321)$ & $6,9(1654)$ & $7,2(1667)$ & \\
\hline & $29,5(13831)$ & $29,0(6919)$ & $30,0(6912)$ & \\
\hline & $27,1(12716)$ & $27,7(6612)$ & $26,5(6104)$ & \\
\hline & $36,4(17068)$ & $36,4(8680)$ & $36,4(8388)$ & \\
\hline \multirow{5}{*}{$\begin{array}{l}\text { Isän koulutus } \\
\text { Peruskoulu tai vastaava } \\
\text { Lukio tai ammatillinen oppilaitos } \\
\text { Lukion tai ammatillisen oppilaitoksen } \\
\text { lisäksi ammatillisia opintoja } \\
\text { Yliopisto, ammattikorkeakoulu tai } \\
\text { muu korkeakoulu }\end{array}$} & & & & \multirow[t]{5}{*}{$<0,001^{2}$} \\
\hline & $10,6(4894)$ & $10,8(2545)$ & $10,3(2349)$ & \\
\hline & $34,2(15828)$ & $34,2(8028)$ & $34,3(7800)$ & \\
\hline & $23,8(11025)$ & $24,6(5780)$ & $23,0(5245)$ & \\
\hline & $31,3(14497)$ & $30,4(7128)$ & $32,4(7369)$ & \\
\hline \multicolumn{2}{|l|}{$\begin{array}{l}\text { Vanhempien työllisyystilanne } \\
\text { Jompikumpi työttömänä tai } \\
\text { pakkolomalla kuluneen vuoden aikana }\end{array}$} & & & \multirow[t]{4}{*}{$<0,001^{2}$} \\
\hline Ei kumpikaan & $67,5(32570)$ & $66,5(16291)$ & 68,5 (16279) & \\
\hline Toinen vanhemmista & $28,6(13813)$ & $29,7(7272)$ & $27,5(6541)$ & \\
\hline Molemmat vanhemmat & $3,9(1875)$ & $3,8(938)$ & $3,9(937)$ & \\
\hline
\end{tabular}

${ }^{1}$ t-testi, ${ }^{2}$ Khiin neliötesti

Vakioidussa mallissa taustatekijöistä tyttöjen luvattomiin poissaoloihin olivat yhteydessä 9. luokka-aste (OR 1,32, lv 1,22-1,43), isän matala koulutus (OR 1,39, lv 1,19-1,61) ja toisen vanhemman työttömyys (OR 1,19, lv 1,09-1,30). Poikien taustatekijöiden vakiointi osoitti luokka-asteen (OR 1,39, lv 1,28-1,51), äidin matalan koulutuksen (OR 1,41, lv 1,17-1,69) ja molempien vanhempien työttömyyden olevan yhteydessä poissaoloihin. (Taulukko 6.)

\section{PERHETEKIJÖIDEN YHTEYS LUVATTOMIIN KOULUPOISSAOLOIHIN}

Kaikki tutkimuksen perhetekijät olivat tilastollisesti merkitsevästi yhteydessä nuorten itsearvioimiin luvattomiin poissaoloihin $(\mathrm{p}<0,001)$. Kahden vanhemman perheessä asuvilla tytöillä ja pojilla oli vähemmän luvattomia poissaoloja kuin muunlaisissa perherakenteissa asuvilla. Yhden vanhemman perheessä asuvien tyttöjen $(27 \%)$ ja poikien $(24 \%)$ luvattomat poissaolot olivat yleisempiä kuin kahden vanhemman perheessä asuvien tyttöjen (14\%) ja poikien (13\%). Eniten luvattomia poissaoloja oli pojilla $(37 \%)$, jotka asuivat jonkun muun kuin oman vanhemman tai vanhempiensa kanssa. Vanhemman ja nuoren välisellä suhteella oli yhteys luvattomiin poissaoloihin. Vähintään yhden päivän luvaton poissaolo oli 34 prosentilla tytöistä ja 33 prosentilla pojista, jotka eivät juuri koskaan keskustelleet omista asioistaan vanhempiensa kanssa. Joka kolmannella tytöllä ja pojalla, jotka eivät saaneet juuri koskaan kotoaan apua koulunkäyntiin, oli luvattomia poissaoloja. Nuoren ja vanhemman välisellä arjen vuorovaikutuksella oli yhteys luvattomiin 
Taulukko 2. 8.- ja 9.-luokkalaisten tyttöjen ja poikien perhetekijät (THL Kouluterveyskysely 2015)

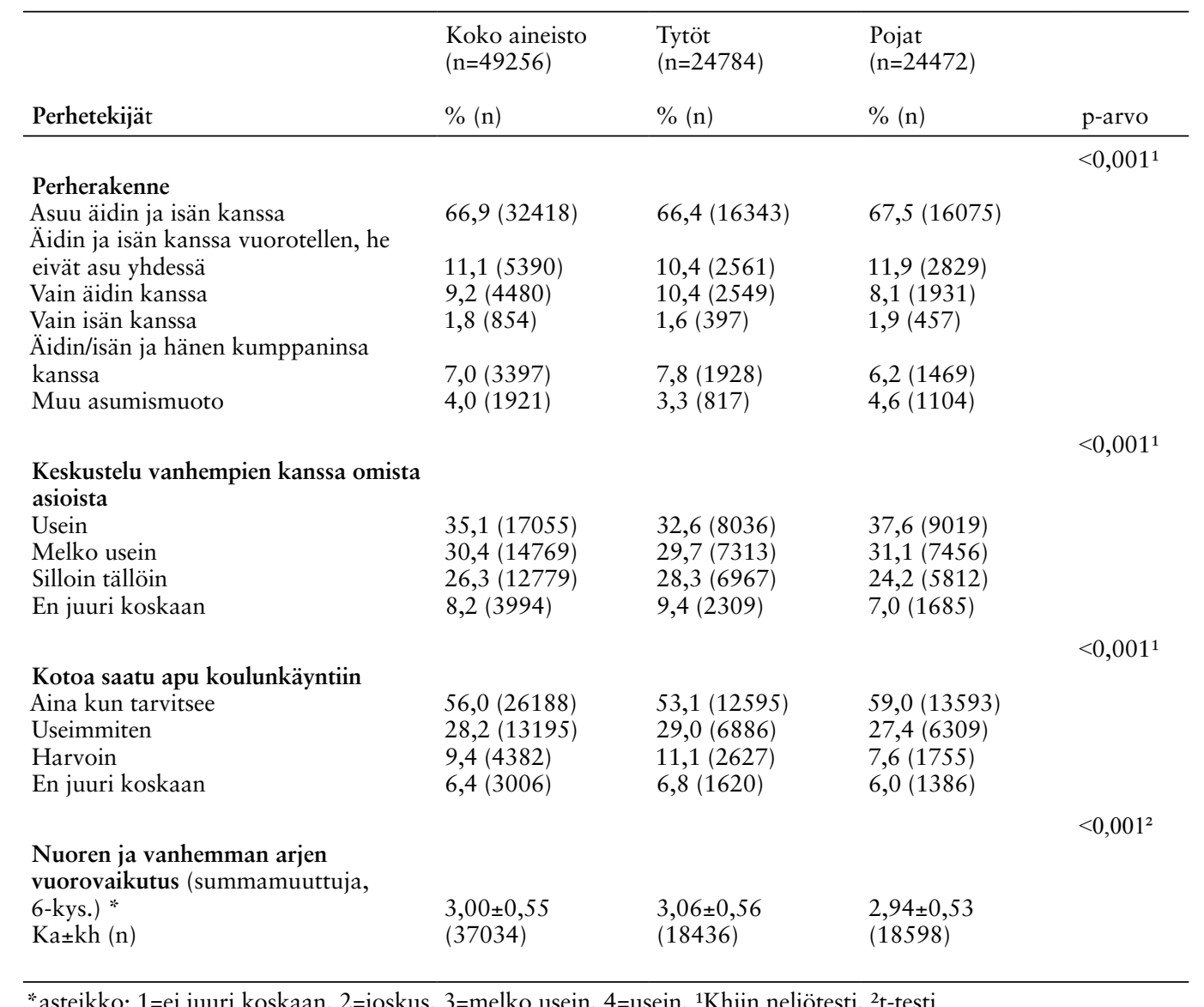

*asteikko: 1=ei juuri koskaan, 2=joskus, 3=melko usein, 4=usein, ${ }^{1}$ Khiin neliötesti, ${ }^{2} \mathrm{t}$-testi

Taulukko 3. 8.- ja 9.-luokkalaisten tyttöjen ja poikien itseraportoitu luvattomien koulupoissaolojen yleisyys (THL Kouluterveyskysely 2015)

\begin{tabular}{|c|c|c|c|c|}
\hline & Koko aineisto & Tytöt & Pojat & \\
\hline $\begin{array}{l}\text { Luvaton poissaolo } \\
\text { viimeisen } 30 \text { päivän aikana }\end{array}$ & $\%(\mathrm{n})$ & $\%(\mathrm{n})$ & $\%(\mathrm{n})$ & p-arvo \\
\hline & & & & $<0,001^{1}$ \\
\hline Ei yhtään & $82,7(37034)$ & $82,3(18436)$ & $83,1(18598)$ & \\
\hline Yhden päivän & $8,9(3965)$ & $9,3(2080)$ & $8,4(1885)$ & \\
\hline 2-3 päivää & $3,8(1714)$ & $4,3(954)$ & $3,4(760)$ & \\
\hline Yli 3 päivää & 4,6 (2057) & $4,2(933)$ & $5,0(1124)$ & \\
\hline
\end{tabular}

${ }^{1}$ Khiin neliötesti 
Taulukko 4. 8.- ja 9.-luokkalaisten tyttöjen ja poikien taustatekijöiden yhteys vähintään yhteen luvattomaan poissaoloon (THL Kouluterveyskysely 2015)

\begin{tabular}{|c|c|c|c|c|}
\hline \multirow[b]{3}{*}{ Taustatekijä } & \multicolumn{4}{|c|}{ Vähintään yksi luvaton poissaolo viimeisen 30 päivän aikana } \\
\hline & Tytöt & & Pojat & \\
\hline & $\%(\mathrm{n})$ & p-arvo ${ }^{1}$ & $\%(\mathrm{n})$ & p-arvo ${ }^{1}$ \\
\hline $\begin{array}{l}\text { Vuosiluokka } \\
\text { 8. luokka } \\
\text { 9. luokka }\end{array}$ & $\begin{array}{l}15,2(1708) \\
20,2(2259)\end{array}$ & $<0,001$ & $\begin{array}{l}14,3(1639) \\
19,5(2130)\end{array}$ & $<0,001$ \\
\hline $\begin{array}{l}\text { Äidin koulutus } \\
\text { Peruskoulu tai vastaava } \\
\text { Lukio tai ammatillinen oppilaitos } \\
\text { Lukion ja ammatillisen oppilaitoksen lisäksi } \\
\text { ammatillisia opintoja } \\
\text { Yliopisto, ammattikorkeakoulu tai muu } \\
\text { korkeakoulu }\end{array}$ & $\begin{array}{l}26,6(395) \\
20,4(1274) \\
16,7(998) \\
14,1(1111)\end{array}$ & $<0,001$ & $\begin{array}{l}29,0(443) \\
18,0(1129) \\
15,0(845) \\
13,9(1062)\end{array}$ & $<0,001$ \\
\hline $\begin{array}{l}\text { Isän koulutus } \\
\text { Peruskoulu tai vastaava } \\
\text { Lukio tai ammatillinen oppilaitos } \\
\text { Lukion ja ammatillisen oppilaitoksen lisäksi } \\
\text { ammatillisia opintoja } \\
\text { Yliopisto, ammattikorkeakoulu tai muu } \\
\text { korkeakoulu }\end{array}$ & $\begin{array}{l}26,1(604) \\
18,6(1354) \\
16,2(851) \\
13,5(868)\end{array}$ & $<0,001$ & $\begin{array}{l}26,4(565) \\
17,0(1212) \\
14,6(701) \\
14,0(948)\end{array}$ & $<0,001$ \\
\hline $\begin{array}{l}\text { Vanhempien työllisyystilanne } \\
\text { Ei työttömyyttä } \\
\text { Toinen vanhemmista työtön } \\
\text { Molemmat vanhemmat työttömänä }\end{array}$ & $\begin{array}{l}15,3(2238) \\
21,3(1412) \\
27,4(238)\end{array}$ & $<0,001$ & $\begin{array}{l}14,7(2185) \\
18,5(1112) \\
32,5(279)\end{array}$ & $<0,001$ \\
\hline
\end{tabular}

${ }^{1}$ Khiin-neliötesti

Taulukko 5. 8.- ja 9.-luokkalaisten tyttöjen ja poikien perhetekijöiden yhteys vähintään yhteen luvattomaan poissaoloon (THL Kouluterveyskysely 2015)

\begin{tabular}{|c|c|c|c|c|}
\hline \multirow[b]{3}{*}{ Perhetekijä } & \multicolumn{4}{|c|}{ Vähintään yksi luvaton poissaolo viimeisen 30 päivän aikana } \\
\hline & Tytöt & & Pojat & \\
\hline & $\%(\mathrm{n})$ & & $\%(\mathrm{n})$ & \\
\hline Asumismuoto & & $<0,001^{1}$ & & $<0,001^{1}$ \\
\hline Ydinperhe & $14,1(2077)$ & & 13,4 (1972) & \\
\hline Vuoroasuminen & $19,6(455)$ & & $17,1(443)$ & \\
\hline Yksinhuoltaja & $27,3(726)$ & & $24,2(530)$ & \\
\hline Uusperhe & $24,6(431)$ & & $20,8(283)$ & \\
\hline Muulla tavoin & $30,8(231)$ & & $37,1(378)$ & \\
\hline $\begin{array}{l}\text { Keskustelu vanhempien kanssa } \\
\text { omista asioista }\end{array}$ & & $<0,001^{1}$ & & $<0,001^{1}$ \\
\hline Usein & $10,4(751)$ & & $12,1(995)$ & \\
\hline Melko usein & $15,4(1018)$ & & $14,8(1015)$ & \\
\hline Silloin tällöin & $22,6(1420)$ & & $20,9(1107)$ & \\
\hline En juuri koskaan & $34,2(728)$ & & $33,2(510)$ & \\
\hline Kotoa saatu apu koulunkäyntiin & & $<0,001^{1}$ & & $<0,001^{1}$ \\
\hline Aina kun tarvitsen & $13,3(1519)$ & & $14,0(1740)$ & \\
\hline Useimmiten & $18,1(1132)$ & & $16,6(962)$ & \\
\hline Harvoin & $27,7(666)$ & & $27,0(440)$ & \\
\hline En juuri koskaan & $36,3(546)$ & & $34,8(449)$ & \\
\hline $\begin{array}{l}\text { Nuoren ja vanhemman arjen vuorovaikutus } \\
\text { (summamuuttuja, 6-kys.) }\end{array}$ & & $<0,001^{2}$ & & $<0,001^{2}$ \\
\hline $\mathrm{Ka} \pm \mathrm{kh}(\mathrm{n})$ & $\begin{array}{l}2,72 \pm 0,60 \\
(3967)\end{array}$ & & $\begin{array}{l}2,68 \pm 0,55 \\
(3769)\end{array}$ & \\
\hline
\end{tabular}

"asteikko: 1=ei juuri koskaan, 2=joskus, $3=$ melko usein, $4=$ usein, ${ }^{1}$ Khiin neliötesti, ${ }^{2}$ t-testi 
Taulukko 6. Tausta- ja perhetekijöiden yhteys vähintään yhteen luvattomaan poissaoloon, tyttöjen ja poikien vakioimattomat ja vakioidut ristitulosuhteet (THL Kouluterveyskysely 2015)

\begin{tabular}{|c|c|c|c|c|c|c|c|c|}
\hline \multirow[b]{2}{*}{ Taustatekijät } & \multicolumn{2}{|c|}{ Tytöt vakioimaton } & \multicolumn{2}{|c|}{$\begin{array}{l}\text { Tytöt } \\
\text { vakioitu }\end{array}$} & \multicolumn{2}{|c|}{$\begin{array}{l}\text { Pojat } \\
\text { vakiomaton }\end{array}$} & \multicolumn{2}{|c|}{$\begin{array}{l}\text { Pojat } \\
\text { vakioitu }\end{array}$} \\
\hline & OR & $95 \% \mathrm{lv}$ & OR & $95 \% \mathrm{lv}$ & OR & $95 \% \mathrm{lv}$ & OR & $95 \% \mathrm{lv}$ \\
\hline $\begin{array}{l}\text { Luokka-aste } \\
8 . \text { luokka }\end{array}$ & 1,00 & & 1,00 & & 1,00 & & 1,00 & \\
\hline 9. luokka & 1,41 & $1,32-1,51$ & 1,32 & $1,22-1,43$ & 1,45 & $1,35-1,55$ & 1,39 & $1,28-1,51$ \\
\hline $\begin{array}{l}\text { Äidin koulutus } \\
\text { Yliopisto, } \\
\text { AMK tai muu } \\
\text { korkeakoulu }\end{array}$ & 1,00 & & 1,00 & & 1,00 & & 1,00 & \\
\hline $\begin{array}{l}\text { Lukion ja } \\
\text { ammatillisen } \\
\text { oppilaitoksen } \\
\text { lisäksi } \\
\text { ammatillisia } \\
\text { opintoja }\end{array}$ & 1,21 & $1,10-1,33$ & 1,07 & $0,95-1,20$ & 1,10 & $0,99-1,21$ & 1,02 & $0,91-1,15$ \\
\hline $\begin{array}{l}\text { Lukio tai } \\
\text { ammatillinen } \\
\text { oppilaitos }\end{array}$ & 1,55 & $1,42-1,69$ & 1,15 & $1,02-1,29$ & 1,36 & $1,24-1,49$ & 1,15 & $1,02-1,30$ \\
\hline $\begin{array}{l}\text { Peruskoulu tai } \\
\text { vastaava }\end{array}$ & 2,19 & $1,92-2,50$ & 1,25 & $1,05-1,48$ & 2,53 & $2,23-2,88$ & 1,41 & $1,17-1,69$ \\
\hline $\begin{array}{l}\text { Isän koulutus } \\
\text { Yliopisto, } \\
\text { AMK tai muu } \\
\text { korkeakoulu }\end{array}$ & 1,00 & & 1,00 & & 1,00 & & 1,00 & \\
\hline $\begin{array}{l}\text { Lukion ja } \\
\text { ammatillisen } \\
\text { oppilaitoksen } \\
\text { lisäksi } \\
\text { ammatillisia } \\
\text { opintoja }\end{array}$ & 1,23 & $1,11-1,37$ & 1,05 & $0,94-1,19$ & 1,04 & $0,94-1,16$ & 0,98 & $0,86-1,11$ \\
\hline $\begin{array}{l}\text { Lukio tai } \\
\text { ammatillinen } \\
\text { oppilaitos }\end{array}$ & 1,45 & $1,33-1,60$ & 1,03 & $0,91-1,16$ & 1,25 & $1,14-1,37$ & 0,99 & $0,88-1,12$ \\
\hline $\begin{array}{l}\text { Peruskoulu tai } \\
\text { vastaava }\end{array}$ & 2,25 & $2,00-2,53$ & 1,39 & $1,19-1,61$ & 2,19 & $1,95-2,47$ & 1,22 & $1,03-1,44$ \\
\hline $\begin{array}{l}\text { Vanhempien } \\
\text { työllisyystilanne }\end{array}$ & & & & & & & & \\
\hline Ei työttömyyttä & 1,00 & & 1,00 & & 1,00 & & 1,00 & \\
\hline $\begin{array}{l}\text { Toinen } \\
\text { vanhemmista }\end{array}$ & 1,50 & $1,39-1,62$ & 1,19 & $1,09-1,30$ & 1,31 & $1,21-1,47$ & 1,13 & $1,01-1,21$ \\
\hline $\begin{array}{l}\text { Molemmat } \\
\text { vanhemmat }\end{array}$ & 2,09 & $1,78-2,44$ & 1,22 & $1,02-1,47$ & 2,78 & $2,40-3,24$ & 1,46 & $1,21-1,76$ \\
\hline
\end{tabular}




\begin{tabular}{|c|c|c|c|c|c|c|c|c|}
\hline \multicolumn{9}{|l|}{ Perhetekijät } \\
\hline $\begin{array}{l}\text { Perherakenne } \\
\text { Ydinperhe }\end{array}$ & 1,00 & & 1,00 & & 1,00 & & 1,00 & \\
\hline Vuoroasuminen & 1,48 & $1,32-1,65$ & 1,45 & $1,28-1,64$ & 1,32 & $1,18-1,48$ & 1,27 & $1,12-1,44$ \\
\hline Yksinhuoltaja & 2,28 & $2,07-2,52$ & 1,69 & $1,51-1,90$ & 2,05 & $1,84-2,29$ & 1,74 & $1,53-1,98$ \\
\hline Uusperhe & 1,98 & $1,76-2,23$ & 1,53 & $1,34-1,75$ & 1,69 & $1,47-1,94$ & 1,40 & $1,20-1,63$ \\
\hline Muulla tavoin & 2,71 & $2,31-3,19$ & 1,48 & $1,21-1,80$ & 3,79 & $3,31-4,34$ & 2,11 & $1,77-2,50$ \\
\hline \multicolumn{9}{|l|}{$\begin{array}{l}\text { Keskustelu } \\
\text { vanhempien } \\
\text { kanssa omista } \\
\text { asioista }\end{array}$} \\
\hline Usein & 1,00 & & 1,00 & & 1,00 & & 1,00 & \\
\hline Melko usein & 1,57 & $1,42-1,73$ & 1,20 & $1,07-1,34$ & 1,26 & $1,15-1,39$ & 1,04 & $0,93-1,15$ \\
\hline Silloin tällöin & 2,52 & $2,29-2,78$ & 1,30 & $1,15-1,47$ & 1,92 & $1,75-2,11$ & 1,14 & $1,01-1,28$ \\
\hline Ei juuri koskaan & 4,51 & $4,01-5,08$ & 1,30 & $1,10-1,54$ & 3,62 & $3,19-4,10$ & 1,21 & $1,01-1,43$ \\
\hline \multicolumn{9}{|l|}{$\begin{array}{l}\text { Kotoa saatu apu } \\
\text { koulunkäyntiin }\end{array}$} \\
\hline Aina kun tarvitsen & 1,00 & & 1,00 & & 1,00 & & 1,00 & \\
\hline Useimmiten & 1,43 & $1,32-1,56$ & 0,99 & $0,90-1,09$ & 1,22 & $1,12-1,33$ & 0,97 & $0,88-1,07$ \\
\hline Harvoin & 2,48 & $2,23-2,75$ & 1,14 & $1,01-1,29$ & 2,28 & $2,02-2,57$ & 1,34 & $1,17-1,55$ \\
\hline Ei juuri koskaan & 3,69 & $3,28-4,15$ & 1,20 & $1,03-1,40$ & 3,28 & $2,89-3,72$ & 1,55 & $1,33-1,82$ \\
\hline $\begin{array}{l}\text { Nuoren ja } \\
\text { vanhemman arjen } \\
\text { vuorovaikutus }\end{array}$ & 0,30 & $0,28-0,32$ & 0,39 & $0,36-0,43$ & 0,35 & $0,24-0,37$ & 0,46 & $0,42-0,50$ \\
\hline
\end{tabular}

Logistinen regressioanalyysi, $\mathrm{OR}=$ ristitulosuhde, $\mathrm{lv}=$ luottamusväli P-arvo $<0,001$ merkitty lihavoituna

poissaoloihin. Luvattomasti poissaolevat arvioivat arjen vuorovaikutuksensa vanhempiensa kanssa huonommaksi kuin ikätoverinsa, joilla ei ollut luvattomia poissaoloja. (Taulukko 5.)

Vakioidun tarkastelun mukaan tyttöjen luvattomiin poissaoloihin olivat perhetekijöistä yhteydessä muu kuin ei kahden vanhemman perheessä asuminen, omista asioista keskustelun puute vanhempiensa kanssa sekä heikompi nuoren ja vanhemman välinen arjen vuorovaikutus (OR 0,39, lv 0,36-0,43). Sen sijaan kotoa koulunkäyntiin saatu apu ei ollut yhteydessä vakioidun tarkastelun mukaan. Poikien luvattomiin poissaoloihin olivat yhteydessä muussa kuin kahden vanhemman perheessä asuminen, kotoa koulunkäyntiin saadun avun puute sekä heikompi nuoren ja vanhemman välinen arjen vuorovaikutus (OR 0,46, lv 0,42-0,50). Sen sijaan omista asioista keskustelu ei ollut enää vakioinnin jälkeen yhteydessä poikien luvattomiin poissaoloihin. (Taulukko 6.)

\section{POHDINTA}

\section{TULOSTEN TARKASTELUA}

Tutkimus osoitti, että lähes joka seitsemäs nuori raportoi vähintään yhden luvattoman poissaolon viimeisen kuukauden aikana. Poissaolojen määrä $(17 \%)$ oli samansuuntainen kuin aiemmissa tutkimuksissa $(39,18,25,26,36)$. Vertailua vaikeuttaa luvaton poissaolo -käsitteen erilaiset määritelmät. Kansallisissa tutkimuksissa luvatonta poissaoloa on tarkasteltu vähintään kahden päivän poissaolona $(6,46)$, jolloin poissaolomäärät ovat jääneet hieman harvemmiksi $(9 \%)$. Aiemmissa tutkimuksissa $(39,18,15,36)$ havaitut tyttöjen poikia yleisemmät luvattomat poissaolot sekä poissaolojen lisääntyminen luokka-asteelta toiselle siirryttäessä tulivat esille osin myös tässä tutkimuksessa.

Vastaajien taustatekijöillä oli tilastollisesti merkitsevä yhteys poissaoloihin. Taustatekijöistä vanhempien koulutustausta ja työllisyystilanne 
olivat yhteydessä luvattomiin poissaoloihin. Tämä tulos tukee aikaisempia tuloksia, joiden mukaan korkeasti koulutettujen vanhempien nuorilla oli vähemmän luvattomia poissaoloja $(26,30)$. Myös aiempien tutkimusten mukaan vanhempien työllisyystilanne oli yhteydessä nuorten luvattomiin koulupoissaoloihin $(11,15,26,40)$. Vanhempien työttömyyden taustalla saattaa kuitenkin olla monia syitä ja niiden syy-seuraussuhdetta ei voitu tässä tutkimuksessa osoittaa. Perheiden köyhyys on monisyinen ongelma, jonka taustalla on muun muassa vanhempien matala koulutus ja työtilanteen muutokset. (47.)

Tutkimus osoitti kaikkien perhetekijöiden yhteyden nuoren luvattomiin koulupoissaoloihin. Muu kuin kahden vanhemman perherakenne, keskustelun puute omista asioista vanhempiensa kanssa ja nuoren kotoa saadun avun puute koulunkäyntiin näyttäytyivät yksittäisessä tarkastelussa olevan yhteydessä luvattomiin poissaoloihin. Kotoa koulunkäyntiin saadulla avulla näyttäisi tämän tutkimuksen mukaan olevan yhteys tyttöjen ja poikien luvattomiin poissaoloihin. Joka kolmas nuori, joka koki kotoa saadun avun puutetta koulunkäyntiin, raportoi myös luvattomista poissaoloista. Vanhempien antama vähäisempi tuki nuoren koulunkäyntiin oli myös aiempien tutkimusten mukaan yhteydessä luvattomiin poissaoloihin $(26,28,40)$.

Nuoren ja vanhemman välisellä arjen vuorovaikutuksella oli tämän tutkimuksen mukaan yhteys vähintään yhden päivän luvattomaan poissaoloon sekä tytöillä että pojilla. Luvattomasti poissaolevat kokivat vuorovaikutuksen heikommaksi kuin säännöllisesti koulutyöhön osallistuvat. Samansuuntaisia tuloksia on saatu kansainvälisissä tutkimuksissa. (24.) Tämä tutkimus toi esiin luvattomasti poissaolevien nuorten kokemat arjen vuorovaikutuksen ongelmat omien vanhempiensa kanssa. PISA-tutkimuksen mukaan vanhemman tuki ja kiinnostus nuoren koulunkäyntiin olivat yhteydessä perheen sosioekonomiseen taustaan voimakkaammin Suomessa kuin muissa maissa. Alhaisemman sosioekonomisen taustan kodeista tulevat nuoret kokivat saaneensa vähemmän tukea koulunkäynnilleen kuin ylimmän sosioekonomisen taustan nuoret. (48.) Nuoruuteen kuuluva irtaantuminen omista vanhemmista saattaa selittää koettua keskustelu- vaikeutta. Kehitysvaiheeseen kuuluvat mielialan vaihtelut, ristiriidat vanhempien kanssa, itsekeskeisyys ja ikätovereiden merkityksen lisääntyminen. Normaalin ja häiriintyneen kehityksen välinen ero saattaa yksilötasolla olla hyvin vähäinen ja vaikeasti erotettavissa. (49.) Tämä tutkimus osoitti luvattomasti poissaolevilla nuorilla olevan ikätovereitaan enemmän negatiiviseksi koettua vuorovaikutusta omien vanhempiensa kanssa.

Laajassa 28 maata käsittävässä tutkimuksessa havaittiin, että koulut, joissa ilmapiiri ja vuorovaikutus perheiden kanssa oli avointa, oli vähemmän luvatonta poissaoloa. Vanhempien tiivis osallistuminen koulun toimintaan on yhteydessä vähäisempiin luvattomiin poissaoloihin. (20.) Myös tämä tutkimus toi esille vanhempien osoittaman mielenkiinnon ja osallistumisen nuoren koulutyön tukemiseen olevan yhteydessä luvattomiin poissaoloihin. Tämän sekä aiempien tutkimusten mukaan näyttäisi siltä, että vahvistamalla nuoren ja vanhemman välistä vuorovaikutussuhdetta ja avun saantia koulukäyntiin voitaisiin luvattomia koulupoissaoloja vähentää.

\section{TUTKIMUKSEN LUOTETTAVUUS}

Kouluterveyskyselyssä on käytetty pääosin samoja muuttujia eri kyselykerroilla, mutta muutamia muuttujia on jätetty pois tai vaihdettu vastausvaihtoehtojen luokitusta. Nuoren ja vanhemman arjen vuorovaikutusta kysyttiin vuoden 2015 kyselyssä aiempaa yksityiskohtaisemmin. (45) Tässä tutkimuksessa nuoren ja vanhemman arjen vuorovaikutusta kuvaava summamuuttuja muodostettiin kuudesta muuttujasta. Summamuuttujan sisäistä johdonmukaisuutta testattiin Cronbachin alfa -kertoimella $(0,61)$, jota voidaan pitää hyväksyttävänä. (50.)

Tyttöjen ja poikien välisen eron pohdintaa vaikeuttaa muuttujien mahdollinen keskinäinen riippuvuus, joka saattaa hankaloittaa regressioanalyysin tulosten tulkintaa ja vaatii lisätutkimuksia (51). Antaako tulos viitteitä siitä, että tytöille on tärkeämpää arjen vuorovaikutus vanhempien kanssa ja pojille taas vanhempien konkreettinen tuki koulutehtävissä?

Mittarin reliabiliteettia arvioitaessa ei tiedetä, miten vastaajat olivat ymmärtäneet kysymykset ja miten heitä oli motivoitu vastaamaan. Tutki- 
muksen aineisto oli nuorten itseraportoimaa, joten vastausharha on voinut vaikuttaa tuloksiin. Vastausharhan minimoimiseksi kaikkia vastaajia oli informoitu vastausten luottamuksellisuudesta. Kuitenkin nuoren luvatonta poissaoloa koskevaan kysymykseen oli jättänyt vastaamatta lähes joka kymmenes tutkimukseen osallistuneista (9\%, n=4486). Lisäksi kysely oli saattanut ajoittua ajankohtaan, jolloin luvattomasti poissaolevat eivät olleet paikalla, ja näin poissaolojen määrä saattoi olla todellisuudessa suurempi. Tutkimusaineiston suuri koko kuitenkin pienentää satunnaisvirhettä.

Kyselyyn vastasi 50404 peruskoulun 8. ja 9. luokan oppilasta. Sukupuolijakauma oli aineistossa tasainen ja ikä rajattu luokka-astetta vastaavaksi. Verrattuna vuoteen 2013 vastaajia oli noin puolet vähemmän. Vastaajien määrän lasku johtui tiedonkeruun teknisistä ongelmista. Sähköisen vastaamisen ongelmat eivät oleellisesti vaikuttaneet vuoden 2015 Kouluterveyskyselyn tulosten raportoitavan tiedon laatuun ja tietoja voidaan pitää kansallisesti yleistettävinä. (45.) Tutkimukseen osallistuneiden määrän ollessa suuri tulokset tulivat helpommin tilastollisesti merkitseväksi. Logistisessa regressioanalyysissa malliin jäi mukaan $82 \%$ tytöistä ja $83 \%$ pojista, joten senkin tulokset kuvasivat hyvin nuorten luvattomiin poissaoloihin yhteydessä olevia tekijöitä.

\section{JOHTOPÄÄTÖKSET JA KEHITTÄMISEHDOTUKSET}

Tämän tutkimuksen perusteella voidaan todeta, että perhetekijöillä ja nuoren luvattomilla poissaoloilla on yhteys. Tutkimus tuotti tietoa suomalaisten nuorten luvattomien koulupoissaolojen ja perhetekijöiden yhteydestä, josta oli aiemmin vain vähäistä tietoa. Saatua tietoa voidaan hyödyntää opiskeluhuoltoa kehitettäessä. Kouluterveydenhuoltoa ohjaavan asetuksen mukaiset 8. luokan laajat terveystarkastukset tarjoavat luontevan mahdollisuuden nuoren ja perheen hyvinvoinnin selvittämiseen. Terveystarkastuksessa arvioidaan nuoren terveyden ja hyvinvoinnin lisäksi vanhempien ja perheen terveyttä, hyvinvointia ja niihin vaikuttavia tekijöitä. (52.) Tutkimus osoitti perusopetuksen yläluokkalaisten ja vanhemman välisen vuorovaikutuksen yhteyden luvattomiin poissaoloihin. Perheen sosioekonomisen tilanteen ja vuorovaikutussuhteiden selvittäminen terveystarkastuksessa kaipaa vielä kehittämistä. Vanhempien omat vaikeudet saattavat rajoittaa heidän nuorelleen antamaa tukea ja siten vaikuttaa myös vuorovaikutussuhteisiin. Vanhemmille ja nuorille on tarpeen korostaa terveystarkastuksien merkitystä koko perheen hyvinvoinnin arvioijana sekä tuen antajana säännölliseen koulutyöhön. Laajat terveystarkastukset tarjoavat ainutlaatuisen mahdollisuuden nuoren, vanhemman, koulun ja kouluterveydenhuollon kohtaamiseen.

Tutkimus toi esiin nuoren itsensä raportoiman luvattomien poissaolojen määrän koulusta. Luvattomien poissaolojen yleisyydestä Suomessa ei ole saatavilla vertailukelpoista tietoa (53). Luvattomiin poissaoloihin reagointi ei ole vain sääntöjen ja ohjeistuksien noudattamista, vaan luvattomaan poissaoloon puuttuminen on aina tärkeää nuoren itsensä kannalta. Poissaolojen systemaattinen kirjaamistapa yhdessä poissaoloihin puuttumisen kanssa on oppilaitoksen velvoite, jolla pyritään tukemaan säännölliseen koulutyöhön osallistumista. Tässä tutkimuksessa luvattomat poissaolot olivat yhteydessä kaikkiin tutkimukseen valittuihin perhetekijöihin. Koulupoissaolot ovat tärkeä hyvinvoinnin seurantamittari ja poissaolojen systemaattisen seurannan avulla on mahdollista selvittää nuoren ja perheen tilannetta tarkemmin. Jatkossa olisi perusteltua tutkia tarkemmin nuoren ja vanhemman välisen vuorovaikutuksen ja poissaolojen yhteyttä laadullisilla tutkimusmenetelmillä. Nuoren omien kokemusten selvittäminen täydentäisi luvattomien koulupoissaolojen taustalla olevien perhetekijöiden merkitystä.

\section{KIRJOITTAJIEN KONTRIBUUTIOT:}

Autio, Joronen ja Rantanen osallistuivat tutkimuksen suunnitteluun. Autio ja Koivisto tekivät analyysit. Autio kirjoitti käsikirjoituksen. Joronen, Koivisto ja Rantanen kommentoivat käsikirjoitusta. 
The aim of this study was to describe the number of self-reported truancy in grades 8 and 9 , and to investigate the connection between background and family factors and these absences. The background factors were the respondent's gender, grade level, education level and employment status of the parents. Family factors included such as the family structure, discussion habits about their personal matters and home help with school and interaction between young and their parents. The data consisted of secondary school students ( $\mathrm{n}$ = 49 256) who responded to the School Health Promotion Study conducted in 2015 by the National Institute for Health and Welfare. Associations between background and family factors and truancy were investigated with logistic regression analysis. The results of the study show that $15 \%$ of the 8 th grade girls and $14 \%$ of the boys had at least one truancy day. Absences were more frequent in the 9th grade: 20 percent of girls and boys reported truancy, respectively. The low edu- cation level and employment status of the parents of the students were connected to absences for both boys and girls. Girls' absences were explained by their 9th grade level, father`s low education, unemployment of the other parent, family structure, less discussion habits about their personal matters and less interaction with their parents. Boys' absences were explained by their grade level, their mother's low education level, unemployment of both parents, family structure, less home help with school and interaction with their parents. Services aimed for young people benefit from identifying the factors related to truancy to better understand the importance of family in the young person's life.

Keywords: absences, adolescent, family, truancy

Saapunut 29.01.2018

Hyväksytty 06.06.2018

\section{LÄHTEET}

(1) POL. Perusopetuslaki 21.8.1998/628. https:// www.finlex.fi/fi/laki/ajantasa/1998/19980628

(2) Opetushallitus. Perusopetuksen opetussuunnitelman perusteet 2014. Luettu 7.12.2017. https://www.oph.fi/ download/163777_perusopetuksen_ opetussuunnitelman_perusteet_2014.pdf

(3) Kuusela J, Peltonen H, Rimpelä M. Poissaolot ja niiden seuranta. Teoksessa Rimpelä M, Rigoff A-M, Kuusela J, Peltonen H. (toimittajat). Hyvinvoinnin ja terveyden edistäminen peruskoulussa - perusraportti kyselystä 7.-9. vuosiluokkien koululle. Opetushallitus, Stakes ja tekijät. 2007. Luettu 7.12.2017. http://www.oph. fi/download/46848_hyvvoinnined.pdf

(4) Fröjd S. Oppilaiden poissaolojen seuranta. Teoksessa Rimpelä M, Fröjd S, Peltonen H. (toim.) Hyvinvoinnin ja terveyden edistäminen perusopetuksessa 2009 Perusraportti. Koulutuksen seurantaraportti 2010:1. Opetushallitus. Helsinki. 2010. Luettu 7.12.2017. http://www.oph.fi/download/124847_ Hyvinvoinnin_ja_terveyden_edistaminen_ perusopetuksessa_2009.pdf

(5) Kaltiala-Heino R, Welling J, Fröjd S. Tamperelaisten 9.-luokkalaisten mielenterveys lukuvuosina 2002-3 ja 2012-13. Pirkanmaan sairaanhoitopiirin julkaisuja 1/2014.

(6) Luopa P, Kivimäki H, Matikka A., ym. Nuorten hyvinvointi Suomessa 2000-2013. Kouluterveyskyselyn tulokset. Terveyden ja hyvinvoinnin laitos, Raportti 25/2014.

(7) Kearney CA. School absenteeism and school refusal behavior in youth: A contemporary review. Clin Psychol Rev 2008;28: 451-471. https://doi.org/10.1016/j.cpr.2007.07.012

(8) Ek H, Eriksson R. Psychological Factors Behind Truancy, School Phobia, and School Re-fusal: A Literature Study. Child Fam Behav Ther 2013;35:228-248. http://dx.doi.org/10.1080/073 17107.2013.818899

(9) Tyrrell M. School Phobia. J Sch Nurs 2005;21: 147-151. https://doi.org/10.1177/10598405050210030401

(10) Berg I. School refusal and truancy. BMJ Open Archive of Diseases in Childhood. 1997;76:90-1. http://dx.doi.org/10.1136/adc.76.2.90

(11) Kaltiala-Heino R, Poutanen P, Kilkku N, ym. Runsaiden koulupoissaolojen yhteys mielenterveysongelmiin yläasteikäisillä nuorilla. Suom laakaril 2003;58:1677-1683.

(12) Gren-Landell M, Allvin CE, Bradley M, ym. Teachers' views on risk factors for problematic school absenteeism in Swedish primary school students. Educ Psychol Pract 2015;31: 412-423. https://doi.org/10.1080/02667363.2015.1086726 
(13) Kearney CA. An Interdisciplinary Model of School Absenteeism in Youth to Inform Professional Practice and Public Policy. Educ Psychol Rev 2008;20:257-282. http://dx.doi.org/10.1007/s10648-008-9078-3

(14) Reid K. Finding strategic solutions to reduce truancy. Rese Educ 2010;84:1-18.

(15) Ingul JM, Klöckner CA, Silverman WK, ym. Adolescent school absenteeism: modelling social and individual risk factors. Child Adolesc Ment Health 2012;17:93-100. http://dx.doi. org/10.1111/j.1475-3588.2011.00615.x

(16) Sheppard A. An Approach to Understanding School Attendance Difficulties: Pupils' Perceptions of Parental Behavior in Response to Their Requests to Be Absent from School. Emo Beha Diffic 2007;12:349-363. https://doi.org/10.1080/13632750701664160

(17) Egger H.L., Costello J, Angold A. School refusal and psychiatric disorders: a community study. J Am Acad Child Adolesc Psychiatry. 2003; 42: 797-807. https://doi.org/ 10.1097/01. CHI.0000046865.56865.79

(18) Henry KL. Who's Skipping School: Characteristics of Truants in 8 th and $10 \mathrm{~h}$ Grade. J Sch Health 2007;77:29-35. https://doi.org/10.1111/j.1746-1561.2007.00159.x

(19) Steinhausen HC, Muller N, Metzke CW. Frequence, stability and differentiation of selfreported school fear and truancy in a community sample. Child Adolesc Psychiatr Ment Health. $2008 ; 2$. https://doi.org/10.1186/1753-2000-2-17

(20) Claes E, Hooghe M, Reeskens T. Truancy as a Contextual and School-Related Problem: A Comparative Multilevel Analysis of Country and School Characteristics on Civic Knowledge among 14 Year Olds. Educ Stud 2009;35:123-142.

https://doi.org/10.1080/03055690802470258

(21) Flaherty C, Sutphen R, Ely G. Examining substance abuse in truant youths and their caregivers: Implications for truancy intervention. Child Sch 2012;34:201-211. https://doi.org/10.1093/cs/cds008

(22) Vaughn M, Maynard B, Salas-Wright C. 2013. Prevalence and correlates of truancy in the US: Results form a national sample. J Adolesc 2013;36:767-76. https://doi.org/10.1016/j. adolescence.2013.03.015

(23) Bailey A, Istre GR, Nie C, ym. Truancy and Injury-Related Mortality. Inj Prev 2017;21:5759.

https://doi.org/10.1136/injuryprev-2014-041276

(24) Okwakpam IN, Okwakpam IO. Causes and levels of truancy among secondary school stu-dents: A case study of Rivers State, Nigeria. Problems of Education in the 21st Century 2012;45:51-62.

(25) Veenstra R, Lindberg S, Tinga F, ym. Truancy in Late Elementary and Early Secondary
Education: The Influence of Social Bonds and Self-Control -The TRAILS Stud. Int J Behav Dev 2010;34:302-310. https://doi.org/10.1177/0165025409347987

(26) Thornton M, Darmody M, McCoy S. Persistent absenteeism among Irish primary school pupils. Educ Rev 2013;65:488-501. https://doi.org/10.1080/00131911.2013.768599

(27) Väänänen J-M, Ranta K, Frödj S, ym. Sosiaalisten tilanteiden pelon ja masennuksen yhteys nuoruusiässä. Suom laakaril 2010;65:3889-3894.

(28) Maynard BR, Salas-Wright CP, Vaughn MG, ym. Who Are Truant Youth? Examining Distinctive Profiles of Truant Youth Using Latent Profile Analysis. J Youth Adolesc 2012;41:1671-1684. https://dx.doi.org/10.1007\%2Fs10964-012-9788-1

(29) Guevara J, Mandell D, Danagoulian S, ym. Parental Depressive Symptoms and Children`s School Attendance and Emergency Department use: A Nationally Representative Study. Matern Child Health J 2013;17:1130-1137. https://doi.org/10.1007/s10995-012-1109-5

(30) Șahin Ș, Arseven Z, Kilic A. Causes of Student Absenteeism and School Dropouts. Int J Instr 2016;9:195-202.

(31) Gottfried M. The Detrimental Effects of Missing School: Evidence from Urban Siblings.

Am J Educ 2011;117:147-182. https://doi.org/10.1085/657886

(32) Kim HY, Page T. Emotional bonds with parents, emotion regulation, and school-related behavior problems among elementary school truants. J Child Fam Stud 2013;22: 869-878. https://doi.org/10.1007/s10826-012-9646-5

(33) Hunt M, Hopko D. Predicting high school truancy among students in the Appalachian South. J Prim Prev 2009;30:549-567. https://doi.org/10.1007/s10935-009-0187-7

(34) Zhang M. Link between School Absenteeism and Child Poverty. Pastoral Care Educ 2003;21:1017. https://doi.org/10.1111/1468-0122.00249

(35) Black AT, Seder RC, Kekahio W. 2014. Review of research on student nonenrolment and chronic absenteeism: A report for the Pacific Region. National Center for Education Evaluation and Regional Assistance. http://ies.ed.gov/ncee/edlabs/ regions/pacific/pdf/REL_2014054.pdf

(36) Askeland K.G, Haugland S, Stormark K.M, ym. 2015. Adolescent school absenteeism and service use in a population-based study. BMC Public Health 2015;15:626. https://doi.org/10.1186/s12889-015-1978-9

(37) Parr AK, Bonitz VS. Role of Family Background, Student Behaviors, and School-Related Beliefs in Predicting High School Dropout. J Educ Res 2015;108:504-514. https://doi.org/10.1080/00220671.2014.917256

(38) Zhang M. School Absenteeism and the Implementation of Truancy-Related Penalty Notices. Pastoral Care Educ 2007;25: 25-34. https://doi.org/10.1111/j.1468-0122.2007.00422.x 
(39) Attwood G, Croll P. 2006. Truancy in Secondary School Pupils: Prevalence, Trajectories and Pupil Perspectives. Res Pap Educ 2006;21: 467-484. https://doi.org/10.1080/02671520600942446

(40) Staudt M. The needs of parents of youth who are truant: Implications for best practices. Best Pract Ment Health 2014;10:47-53.

(41) Duarte R, Escario J.J. Alcohol Abuse and Truancy among Spanish Adolescents: An Count-Data Approach. Econ Educ Rev 2006;25:179-187. https://doi.org/10.1016/j. econedurev.2005.01.007

(42) Epstein J, Sheldon S. Present and accounted for: Improving student attendance through family and community involvement. J Educ Res 2002;95:308- 317. https://doi.org/10.1080/00220670209596604

(43) Wallerstein J, Lewis J, Rosenthal S.Mothers and their children after divorce: Report from a 25-year longitudinal study. Psychoanal Psychol 2013;30:167-187. http://psycnet.apa.org/ doi/10.1037/a0032511

(44) Kearney CA. Forms and Functions of School Refusal Behavior in Youth: An Empirical Analysis of Absenteeism Severity. J Child Psychol Psychiatry 2007;48:53-61.

https://doi.org/10.1111/j.1469-

7610.2006.01634.x

(45) Halme N, Kivimäki H, Luopa P, ym. Kouluterveyskysely 2015. Oppilaitos-, opetuspiste- ja kuntakohtaisten tulosten raportointi. Terveyden ja hyvinvoinnin laitos. 2016.

(46) Matikka A, Luopa P, Kivimäki H, Jokela J. \& Paananen R. Maahanmuuttajataustaisten 8. ja 9.-luokkalaisten hyvinvointi. Kouluterveyskysely 2013. Terveyden ja hyvinvoinnin laitos, Raportti 26/2014.

(47) Karvonen S, Salmi M. (toim.) Lapsiköyhyys Suomessa 2010-luvulla. Terveyden ja hyvinvoinnin laitos, Työpaperi 30/2016.

(48) Välijärvi J. PISA 2015 Oppilaiden hyvinvointi. Jyväskylän yliopisto. Koulutuksen tutkimuslaitos. 2017 Luettu 7.12.2017. https://ktl.jyu.fi/ julkaisut/julkaisuluettelo/julkaisut/2017/ KTL-D118
(49) Aalto-Setälä T, Marttunen M. Nuoren psyykkinen oireilu - häiriö vai normaalia kehitystä? Duodecim 2007;123:207-213.

(50) Heikkilä T. Tilastollinen tutkimus. 9. uudistettu painos. Edita Publishing, Helsinki.2014.

(51) KvantiMOTV. 2017. Regressioanalyysi. Luettu 7.12.2017.http://www.fsd.uta.fi/ menetelmaopetus/logregresio/logistinen.html.

(52) VNA 338/2011. Valtioneuvoston asetus neuvolatoiminnasta, koulu- ja opiskeluterveydenhuollosta sekä lasten ja nuorten ehkäisevästä suun terveydenhuollosta 338/2011. Luettu 7.12.2017. http://www.finlex.fi/fi/laki/al-kup/2011/20110338

(53) Terveyden ja hyvinvoinnin laitos. 2016b. Hyvinvoinnin ja terveyden edistäminen peruskouluissa - TEA 2015.Luettu 7.12.2017. https://www.teaviisari.fi/teaviisari/fi/tulokset

\section{Eva Autio}

TtM, erikoissuunnittelija

Terveyden ja byvinvoinnin laitos (THL)

Lapset, nuoret ja perheet $-y k$ sikkö

\section{Anja Rantanen}

TtT, dosentti, yliopisto-opettaja

Tampereen yliopisto

Yhteiskuntatieteiden tiedekunta

Anna-Maija Koivisto

FM, yliopisto-opettaja

Tampereen yliopisto

Yhteiskuntatieteiden tiedekunta

KATJA JORONEN

TtT, dosentti, yliopistonlehtori

Tampereen yliopisto

Yhteiskuntatieteiden tiedekunta 